\title{
5 | Water and rights: state management in South Africa and India
}

\author{
LYLA MEHTA, LISA THOMPSON AND \\ NDODANA NLEYA
}

This chapter examines the relationship between citizens mobilizing for their rights to water in South Africa and India and the ways in which state policies may hinder the acquisition of socio-economic rights, even where the policies themselves are ostensibly aimed at promoting the socio-economic interests of the poor. As discussed in the introductory chapter, the ways in which poor communities mobilize to claim rights is essential to understanding how socio-economic rights make a difference to the lives of the poor, but the other side of the equation is what state actors' responses are to different types of mobilization in relation to problems of policy implementation. This chapter illustrates that even when such rights are upheld by international laws, as well as national policies, they may still have to be fought for by ordinary citizens, and may be denied by the state in a number of ways. We refer here to the relationship between what Mehta (2006) has called 'sins of omission' and 'sins of commission' on the part of governments upholding rights in legal terms as well as in the ways they mediate citizens' claims for both negative and positive rights. ${ }^{1}$

In this regard, sins of omission ${ }^{2}$ are understood as situations in which governments may by default deny citizens access to social and economic rights. It is well known that poor states may not prioritize the imperative to provide education, water and housing for all. Also, many developing countries may lack the resources to provide rights to all citizens to live a life in dignity or else may lack the institutional capacity to provide these rights. Similarly, citizens may not be aware of rights and may not have the capacity to mobilize around them, or may mobilize in fragmented and unorganized ways that do not significantly impact on government policies or behaviour. It is well known that social movements are generally discouraged by governments in the South (see Thompson and Mahmud, this volume, as well as Bond et al. 2001). This relates to what Mehta (2006) describes as sins of commission. Here states or international non-governmental actors such as the World Bank may knowingly put 
vulnerable people's rights at risk or even violate them for a variety of reasons. For example, the freedom of speech and right to protest are severely restricted in times of dictatorships. Rights may also be violated in the name of 'development'. This chapter demonstrates how in the case of India, dam-building causes forced displacement which infringes on displaced people's rights to livelihood, land, water, and so on. Moreover, in the South African case, a combination of sins of omission and commission play themselves out owing largely to an uneasy mix of official socio-economic entitlements to water which are in conflict with broader macroeconomic policies.

Mobilization often occurs around citizens' demands for rights bestowed on them constitutionally and in terms of both national and international norms and policy declarations. This chapter examines the linkages between rights 'on paper' and rights 'in practice' by focusing on the sins of omission and commission that have taken place in the relation to how Indian and South African governments have mediated their constitutional and policy commitments to the right to water in relation to the claims of poor communities, as well as how communities have mobilized to claim back these rights.

In 2002, the UN Economic, Social and Cultural Council gave a lot of prominence to the right to water through its General Comment No. 15, which is an authoritative interpretation of the International Covenant on Economic, Social and Cultural Rights, 1966, which implicitly points towards the recognition of the right to water. The Comment, a non-legally binding document, stated explicitly that the right to water is a human right and that responsibility for the provision of sufficient, safe, affordable water to everyone, without discrimination, rests with the state. Still the right to water is very controversial on many fronts. While in principle it is accepted that there is an 'indivisibility' of civil and political rights on the one hand, and economic, cultural and social rights on the other, in practice there is still no equal recognition, and there is the assumption that economic and social rights can be realized only once the so-called first generation of rights are realized. Furthermore, in the water debate, dominant narratives, especially with the passage of the four so-called 'Dublin principles' (ICWE 1992), more often see water as an economic good rather than as a human right. South Africa, however, stands out in this regard and is among the seven countries with a constitutional right to water, alongside Ethiopia, Uganda, Gambia, Uruguay, Panama and Zambia (COHRE 2006, in Anand 2007; Gowlland-Gualtieri 2007). The case study examples discussed here show that there is no direct relationship 
between rights 'on paper' and rights 'in practice'. Nor is there necessarily a causal relationship between mobilization and achieving rights, especially socio-economic rights. In the South African case, the role of mediating social movements like the Coalition against Water Privatisation has enabled marginalized communities to mobilize for their rights, and in India social movement activity has also helped to frame rights discourses more effectively. Yet the Indian case also calls into question the ability of social movement activity to change the course of government policy, especially where sins of commission have taken place.

South Africa's policies relating to the provision of water examine how sins of omission largely prevent many vulnerable groups from having access to the right to water in South Africa, where the lack of financial resources, poor institutional capacity and very little knowledge of rights prevent them from being realized and claimed by citizens. The sins of commission relating to the clash of free basic water (FBW) policies with privatization and cost recovery, which put basic rights at risk, are also discussed. The chapter also examines the ways in which the state mediates the socio-economic claims of citizens through various forms of participation and mobilization, and in so doing sometimes acts in contradictory ways, for example in the South African case, on the one hand enforcing socio-economic entitlements (FBW) and on the other hand undermining these rights (through the installation of water meters, for example).

The Indian case examines government sins of commission where displaced people's rights are both put at risk and blatantly violated through processes of forced displacement as a consequence of dam-building. It focuses on how states and agencies such as the World Bank knowingly put both negative and positive rights at risk in the name of 'development'. Even though policy safeguards are in place to ostensibly mitigate the risks of forced displacement, the history of dam-building is characterized by a string of human rights violations, as well as depriving communities of their livelihoods. These issues are examined by looking at the case of the Narmada dams in India and by asking how and whether agencies such as the Indian government and the World Bank can be held accountable, in particular how communities and globally based social movements help to channel rights claims and accountability issues.

Both South Africa and India experience challenges of water provision to the poor and periods of water shortage. Post-apartheid South Africa has one of the world's most dynamic water ministries committed to overcoming the problems of poor water access and provision and water scarcity, and is striking in explicitly recognizing the human right to water. 